${ }^{1}$ A. Хуссейн, ORCID: 0000-0001-6095-1260<abid.hussain@seecs.edu.pk> 2 M. Сафьян, ORCID: 0000-0003-4501-9699<msafyan@gcul.edu.pk ${ }^{3}$ C. Capвap, ORCID: 0000-0001-9714-6580<sohail.sarwar@seecs.edu.pk> 3 3.Уль Кайум, ORCID: 0000-0003-4230-6895<zia@aiou.edu.pk>

\section{Mitigating MAC Layer Performance Anomaly of Wi-Fi Networks through Adaptable Channelization}

${ }^{1}$ A. Hussain, ORCID: 0000-0001-6095-1260 <abid.hussain@seecs.edu.pk> ${ }_{2}^{2}$ M. Safyan, ORCID:0000-0003-4501-9699<msafyan@gcul.edu.pk

${ }^{3}$ S. Sarwar, ORCID: 0000-0001-9714-6580<sohail.sarwar@seecs.edu.pk>

${ }^{3}$ Z. Ul Qayyum, ORCID: 0000-0003-4230-6895<zia@aiou.edu.pk> ${ }_{4.5}$ M. Iqbal, ORCID:0000-0002-8438-6726<m.iqbal@lsbu.uk>

${ }^{1}$ N.A. Saqib, ORCID: 0000-0003-1976-0643<nazrabbas@eme.edu.pk>

${ }^{1}$ School of Electrical Engineering and Computer Science, NUST, Pakistan

${ }^{2}$ Department of Computing, GC University Lahore, Pakistan

${ }^{3}$ Department of Computer Science, University of Gujrat, Pakistan

${ }^{4}$ School of Engineering London South Bank University, England

${ }^{5}$ School of Computer Science and Electronic Engineering University of Essex, England

Abstract. 802.11 wireless local area networks (WLANs) can support multiple data rates at physical layer by using adaptive modulation and coding (AMC) scheme. However, this differential data rate capability introduces a serious performance anomaly in WLANs. In a network comprising of several nodes with varying transmission rates, nodes with lower data rate (slow nodes) degrade the throughput of nodes with higher transmission rates rates, ness. The restes (fast nodes). The prich ensures long term equal chan investigate the use of ad a performance It has been observed that surplus channel-widh due to lower transmission rate of slow nodes can be assigned to fast nodes connected to other access points (APs), which can substantially increase the overall throughput of the whole network. We propose a medium access control (MAC) layer independent anomaly prevention (MIAP) algorihm that assigns chan a medien accion rate. We have modeled the effect of adaptable channelization and provide lower and upper bounds for throughput in various network scenarios. Our empirical results indicate a possible increase in network throughput by more than $20 \%$ on employing the proposed MIAP algorithm.

Keywords: Transmission Rates; Channel Access; Adaptive Channel; Anomaly Prevention; Throughput For citation: Hussain A., Safyan M., Ul Qayyum Z., Sarwar S., Iqbal M., Saqib N.A. Mitigating MAC Layer Performance Anomaly of Wi-Fi Networks through Adaptable Channelization. Trudy ISP RAN/Proc. ISP RAS, vol. 31, issue 2, 2019. pp. 53-66. DOI: 10.15514/ISPRAS-2019-31(2)-5
4,5 M. Икбал, ORCID:0000-0002-8438-6726<m.iqbal@lsbu.uk>

${ }^{1}$ H.A. Сакиб, ORCID: 0000-0003-1976-0643 <nazrabbas@eme.edu.pk>

${ }^{1}$ Школа электротехники и информатики,

Национальныий университет наук и технологий, Пакистан

2 Правительственный университет колледжа, Лахор, Пакистаи

${ }^{3}$ Университет Гуджарата, Пакистан

${ }^{4}$ Лондонский университет Саут Бэнк, Великобритания

${ }_{5}^{5}$ Университет Эссекса, Великобритания

Аннотация. Беспроводные локальные сети (WLAN) 802.11 могут поддерживать несколько скоростей передачи данных на физическом уровне с использованием схемы адаптивной модуляции и кодирования (AMC). Однако эта возможность поддержки разных скоростей передачи данных вызывает в WLAN серьезную аномалию производительности. В сети, состоящей из нескольких узлов с разными скоростями передачи, узлы с более низкой скоростью передачи данных (медленные узлы) ухудшаю пропускную способность узлов с более высокими скоростями передачи (быстрые узлы). Основным источником этой аномалии является механизм доступа к каналу WLAN, который обеспечивае долгосрочную равную вероятность доступа к каналу для всех узлов независимо от их скоростей передачи. В этой работе мы исследуем использование адаптируемого разделения на каналы по ширине, чтобы минимизировать влияние этого явления на производительность. Отмечается, что ширина канала, избыточная из-за более низкой скорости передачи медленных узлов, может быть назначена быстрым узлам, подключенным к другим точкам доступа (АР), что может существенно увеличить общую пропускную способность всей сети. Мы предлагаем алгоритм предотвращения аномалий на уровне управления доступом к среде (МAC), который назначает ширину канала узлам, связанным различными точками доступа, на основе их скорости передачи. Мы смоделировали эффект адаптивного разделения на қаналы и установили нижнюю и верхнюю границы пропускной способности в различных

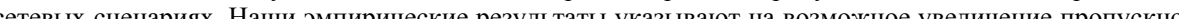
способности сети более чем на $20 \%$ при использовании предложенного алгоритма MIAP.

Ключевые слова: скорость передачи; доступ к каналу; адаптивный канал; предотвращение аномалий; пропускная способность

Для цитирования: Хуссейн А., Сафьян М., Сарвар С., Ул Кайум 3., Икбал М., Сакиб Н.А. Сглаживание аномалий производительности сетей Wi-Fi на уровне МАC путем адаптивного выделения каналов Труды ИСП РАН, том 31, вып. 2, 2019 г., стр. 53-66 (на английском языке). DOI: 10.15514/ISPRAS-2019$31(2)-5$

\section{Introduction}

The exponential increase in wireless enabled devices requires maximum capitalization of available resources in WLANs. This imminent requirement has triggered the re-evaluation of wireless protocols. Today's WLANs acclimatize several transmission parameters to achieve optimal network performance. However, some of the parameters like channel width and MAC layer functioning still remain static resulting in sub-optimal network performance.

Authors in [8] provide a detailed analysis of a performance anomaly at MAC layer of WLANs. If a wireless cell contains nodes with varying data rates, the throughput performance of fast nodes decreases substantially due to longer channel capturing of slow nodes. In [8] authors analytically modeled this anomalous behavior which is applicable to any multi- rate 802.11 network that uses 
contention based channel access mechanism[1] at MAC layer. If $X_{s}$ and $X_{f}$ are throughputs of slow and fast nodes respectively, these can be measured as given in equation 1

$$
X_{s}=X_{f}=\frac{S_{d}}{(N-1) T_{f}+T_{s}+P_{c}(N) \times t_{j a m} \times N},
$$

where $S_{d}$ is frame size, $N$ is the number of wireless nodes, and $T_{f}$ and $T_{s}$ are transmission times of fast and slow nodes respectively. $P_{c}(N)$ is collision probability and $t_{j a m}$ is the time elapsed in collision.

Equation 1 is applicable only to single cell networks. However, rapid improvements in wireless technologies have shifted the paradigm of few users, single AP networks to several APs and numerous users per AP environments. We found that substantial increase in network wide performance is achievable if we divert network resources from a cell with limited need to another resource hungry cell. Adaptable width channelization [9] has been used to achieve this intelligent diversion of resources.

In this work, we propose MIAP algorithm that uses adaptable channelization to minimize the effect of MAC layer performance anomaly. The elementary concept of MIAP is to assign channels with high level of granularity thus maximizing the spectrum utilization. A node with low SNR values and subsequent low transmission rate transmit at narrow channel width and vice versa. In addition to this, use of adaptable channelization is independent of MAC layer and do not require any modification in channel access mechanism. It ensures that long term channel access probability of all the nodes remains equal and slow nodes do not suffer starvation. The channel width is adjusted by adding different number of sub-carriers. The use of narrower channels at nodes with lower SNR values adds several benefits to communication. Since narrower channels have higher spectral efficiency, it increases SNR of nodes. The performance of MIAP algorithm is measured on essential network parameters like network throughput, fairness index and frame size. The contributions of this research work can be outlined as follows.

1) Implementation of MAC layer independent channel width adaptation algorithm for minimizing the effect of MAC layer performance anomaly.

2) Analysis of proposed algorithm by measuring its effect on essential network parameters like throughput, fairness of channel access mechanism and frame size.

3) Implementation of proposed algorithm on real test-bed of USRP devices for accurate performance measurements.

The rest of this paper is organized as follows. Section 2 provides an overview of research work and proposed method for elimination of MAC layer performance anomaly. Section 3 presents the problem formulation and analytically models the solution. We have explained our proposed algorithm in Section 4. Section 5 explains the test-bed environment and experimentation methodology. Achieved results and discussion on these results are presented in section 6 . Finally, we have concluded this work in Section 7.

\section{Related Work}

A substantive research on mitigating the effect of MAC layer performance anomaly in multi-rate WLANs has been presented in literature. The work proposed in [2][11][13][15] are of premier importance to this research study. In [13] authors have proposed an algorithm for performance anomaly reduction using open flow access points. The proposed model jointly reduces the effect of performance anomaly and number of hand offs, thus maximizing throughput by $26.7 \%$. The research work given in [15] proposes a modification to control packets by embedding the data rate of two hops neighbors. In response to this control packet, the nodes adjust the initial value of contention window (CWmin) according to the data rate of neighboring nodes. In [11] authors claim that the performance anomaly model presented in [8] is only valid for networks having static channel characteristics. The nodes with better Signal-to-Noise (SNR) have higher channel access rate as compared to nodes having lower SNR. This assertion ensures that the effect of MAC laye performance anomaly can be substantially reduced by using time-varying and time-correlated channels with Rayleigh fading effects.

The work presented in [2] mitigates the effect of MAC anomaly by controlling the value of backoff contention window based on signal strength of a node. Authors have concluded that, lower values of contention window for nodes having higher SNR considerably reduces the effect of MAC anomaly. In [12] an anomaly mitigation scheme for TCP friendly rate control (TFRC) protocol is presented. We named this approach as channel occupancy time based anomaly mitigation (COTAM). In this approach nodes estimate their share of leftover channel occupancy time and only make their communication in that slot. Majority of the techniques for mitigation of MAC layer anomaly restricts the channel access of nodes having lower transmission rate. This methodology adds further disadvantage to already poor performance of these nodes. This below par performance of slower nodes, in turns negatively affects the overall performance of complete network. The use of adaptable channelization has gained significant importance in recent studies [9][16].

The concept of adaptable channelization involves the granular use of available frequency spectrum. Research in [5][9][16] shows that a considerable increase in network capacity can be achieved if we use channels of adaptable widths. Since the advent of flexible channelization concept with the work presented on [5], the main focus of researchers remains on physical layer parameters, like transmission rate, interference, power consumption, delay spread and likewise. To best of our knowledge, to-date, no study for effect of flexible channelization on MAC layer is presented in literature.

\section{Problem Formulation}

802.11 networks use two spectrum blocks for their communication. These blocks consist of $2.4 \mathrm{GHz}$ and $5 \mathrm{GHz}$ frequency ranges. In this work, we are emphasizing only $2.4 \mathrm{GHz}$ frequency spectrum used by $802.11 \mathrm{~b} / \mathrm{g} / \mathrm{n}$ networks for proof of concept purpose. The total available spectrum block in $802.11 \mathrm{~b} / \mathrm{g} / \mathrm{n}$ networks is divided into 14 channels of equal width of $22 \mathrm{MHz}$ each [1]. To minimize the effect of co-channels interference (CCI), a guard band of $5 \mathrm{MHz}$ is incorporated between any two consecutive channels. Each $22 \mathrm{MHz}$ Wi-Fi channel is constituted of 52 sub-carriers. Out of these 4 sub-carriers are used for control signals while rest of 48 sub-carriers are used for data symbols [1]. The physical layer of Wi-Fi networks spread the data symbols on these 48 sub-carriers through orthogonal frequency division multiplexing (OFDM) or direct sequence spread spectrum (DSSS). The DSSS is only used to support legacy Wi-Fi devices like $802.11 \mathrm{~b}$.

\subsection{Network Model}

Consider a network of $N_{t}$ nodes operating at transmission rate $R$. The set of $N_{t}$ nodes is divided in two subsets of and $N_{f}$ such that $N_{s}, N_{f} \subset N_{t}$ and $N_{s} \cup N_{f}=N_{t}$ where $N_{s}$ consists of all the nodes transmitting below a threshold transmission rate $R_{s}$ and referred as slow nodes. The other subset of $N_{f}$ nodes transmit above the threshold transmission rate $\left(R_{S}\right)$ and referred as fast nodes. The $N_{t}$ nodes of network are associated with $K_{t}$ access points with $K_{i}$ denoting any $i$ th AP. The set of nodes associated to any AP $K_{i}$ is $n_{t}$ such that $n_{t}=n_{s} \cup n_{f}, n_{t} \subset N_{t}, n_{s} \subset N_{s}$, and $n_{f} \subset N_{f}$ where $n_{s}$ and $n_{s}$ are the sets of slower and faster nodes attached to any single AP $K_{i}$. The $K_{t}$ access points of network form $K$ identifical circles in which their transmission can be received and decoded correctly. The association of nodes with an AP is independent of each other and follows Poisson distribution with probability density function as given by equation 2

$$
\operatorname{Pr}\left\{n_{t} \rightarrow K_{i}\right\}=\frac{\lambda^{n_{t}} e^{-\lambda}}{n_{t} !}
$$

where $n_{t} \rightarrow K_{i}$ denotes the total number of nodes $\left(n_{t}\right)$ associated to an access point $K_{i}$ 
Consider the probability of a slow and a fast node connected to an AP $K_{i}$ is $\rho$ and $(1-\rho)$ respectively. Then the joint probability distribution of slower and faster nodes attached to any AP $K_{i}$ is given by

$$
\operatorname{Pr}\left\{\left(n_{s} \wedge n_{f}\right) \rightarrow K_{i}\right\}=\rho^{n_{s}}(1-\rho)^{n_{t}-n_{s}}
$$

The probability that exactly $s$ number of slow nodes are attached to any AP $K_{i}$ at any given time $t_{i}$ can be given as

$$
\operatorname{Pr}\left\{\left(n_{s}=s\right) \rightarrow K_{i}\right\}=\left(\begin{array}{c}
n_{s} \\
s
\end{array}\right) \rho^{s}(1-\rho)^{n_{s}-s}
$$

for $s=0,1,2, \ldots, n_{s}$ and $n_{s}=0,1,2, \ldots, n_{t}$.

The probability that maximum number of slow nodes attached to any AP $K_{i}$ at any given time $t_{i}$ is less than $s$ can be given as

$$
\operatorname{Pr}\left\{\left(n_{s}<s\right) \rightarrow K_{i}\right\}=\sum_{s=0}^{n_{s}}\left(\begin{array}{l}
n_{s} \\
s
\end{array}\right) \rho^{s}(1-\rho)^{n_{s}-s}
$$

In a similar way, the probability that exactly (or less than) $f$ number of fast nodes are attached to any AP $K_{i}$ at any given time $t_{i}$ will be

$$
\begin{gathered}
\operatorname{Pr}\left\{\left(n_{f}=f\right) \rightarrow K_{i}\right\}=1-\left(\begin{array}{l}
n_{s} \\
s
\end{array}\right) \rho^{s}(1-\rho)^{n_{s}-s} \\
\operatorname{Pr}\left\{\left(n_{f}<f\right) \rightarrow K_{i}\right\}=1-\sum_{s=0}^{n_{s}}\left(\begin{array}{l}
n_{s} \\
s
\end{array}\right) \rho^{s}(1-\rho)^{n_{s}-s}
\end{gathered}
$$

for $f=0,1,2, \ldots, n_{f}$ and $n_{f}=0,1,2, \ldots, n_{t}$.

Similarly, the probability for slow and fast nodes operating in whole network at any given time $t$ can be calculated by using equation 8 and 9 respectively.

$$
\operatorname{Pr}\left\{\left(N_{s} \leq S\right) \rightarrow K_{i}\right\}=\sum_{S=0}^{N_{S}}\left(\begin{array}{c}
N_{S} \\
S
\end{array}\right) \rho^{S}(1-\rho)^{N_{S}-S}
$$

for $S=0,1,2, \ldots, N_{s}$ and $N_{s}=0,1,2, \ldots, N_{t}$

$$
\operatorname{Pr}\left\{\left(N_{f} \leq F\right) \rightarrow K_{i}\right\}=1-\sum_{S=0}^{N_{S}}\left(\begin{array}{l}
N_{s} \\
s
\end{array}\right) \rho^{S}(1-\rho)^{N_{s}-S}
$$

\subsection{Throughput and Adaptable Channel}

Let us assume that the network model given in subsection 3.1 uses $L$ transmission channels $L_{1}, L_{2} \ldots, L_{u}$ for communication with $L_{i}$ representing the $i$ th channel. According to the throughput calculations given in [17], the channel capacity $C$ (or maximum achievable throughput $T$ ) of a node operating on static width communication channel of bandwidth $B$ in the presence of noise is $T=$ $B \log _{2}(1+\operatorname{SINR}(d B))$ and $\operatorname{SINR}(d B)=10 \log _{10} \operatorname{SINR}$. The achievable throughput of any node $N_{i}$ (slower or faster) can be written as follows.

$$
T\left(N_{i}\right)=B \log _{2}\left(1+10 \log _{10} \operatorname{SINR}\left(N_{i}\right)\right)
$$

Authors in [4] have calculated signal to interference plus noise ratio (SINR) for static width channels. We can extend the same approach to get $\operatorname{SINR}$ for varying channel widths as follows

$$
\operatorname{SINR}\left(N_{i}\right)=\frac{P d\left(J_{i}, K_{i}\right)^{-\alpha}}{\delta+P \sum \varphi\left(L_{i}, L_{j}\right) d\left(K_{i}, K_{j}\right)^{-\alpha}}
$$

for $L_{i} \& L_{j} \in L ; K_{i} \& K_{j} \in K ; L_{i} ! \rightarrow K_{i}$ and $L_{j} \rightarrow K_{j} ; i \neq j$. Here $P$ is the transmission power, $d\left(N_{i}, K_{i}\right)$ is the distance between node $N_{i}$ and access point $K_{i}, \delta$ is the path loss, which varies from 2 to 4 for a typical 802.11 network, $\alpha$ is the ambient noise, and $\varphi\left(L_{i}, L_{j}\right)$ is the partial overlapping degree between channel $L_{i}$ and $L_{j}$. This partial overlapping degree is given in [9]. The expression
$L_{i} ! \rightarrow K_{i}$ shows that channel $L_{i}$ is not associated to access point $K_{i}$, and the expression $L_{i} \rightarrow K_{i}$ shows that channel $L_{i}$ is associated to access point $K_{i}$ Equation 11 is true when the network operates in saturation mode, that is, all the APs have data to send or receive and not idle at any time. As this is not always true, it is generalized as shown in equation 12 below.

$$
\operatorname{SINR}\left(N_{i}\right)=\frac{P d\left(J_{i}, K_{i}\right)^{-\alpha}}{\delta+P \beta\left(L_{i}\right) \sum \varphi\left(L_{i}, L_{j}\right) d\left(K_{i}, K_{j}\right)^{-\alpha}},
$$

where $\beta\left(L_{i}\right)$ is the probability of channel occupation of any channel $L_{i}$. It is '1' when the network operates in saturation mode showing that all available channels have been occupied by the APs. By substituting the value of $\operatorname{SINR}\left(N_{i}\right)$ in equation 10 from equation 12 we have

$$
T\left(N_{i}\right)=B \log _{2}\left(1+10 \log _{10} \frac{P d\left(J_{i}, K_{i}\right)^{-\alpha}}{\delta+P \beta\left(L_{i}\right) \sum \varphi\left(L_{i}, L_{j}\right) d\left(K_{i}, K_{j}\right)^{-\alpha}}\right)
$$

Equation 13 gives the throughput of a single node of network irrespective of its transmission rate. It is evident that throughput of any node is a function of available bandwidth $(B)$. If a node is transmitting at a slower rate, it means that its bandwidth requirement is inherently less, which can be diverted to faster nodes.

$$
T=B \sum_{i=1}^{N} \log _{2}\left(1+10 \log _{10} \frac{P d\left(J_{i}, K_{i}\right)^{-\alpha}}{\delta+P \beta\left(L_{i}\right) \sum \varphi\left(L_{i}, L_{j}\right) d\left(K_{i}, K_{j}\right)^{-\alpha}}\right)
$$

\subsection{Mitigating the Effect of MAC Performance Anomaly}

The bandwidth $(B)$ of a channel is a sum of individual bandwidths of its sub-carriers. Using adaptable channelization we can increase or decrease the width of channel by varying the number of sub-carriers in that channel accordingly. In this work, we have varied the number of sub-carriers from 12 (5 MHz channel width) to 72 (30 MHz channel width).

Let us consider that $N_{t}$ wireless nodes are distributed randomly across $N_{t}$ APs. The transmission probability of a slower node is $\tau_{s}$ and transmission probability of faster node will then be $\left(1-\tau_{s}\right)$ The probability that at any given time, only slow nodes are transmitting in each cell will be $\tau_{s}{ }^{K_{t}}$ Similarly, the probability that only faster nodes are transmitting in a cell will be $\left(1-\tau_{s}\right)^{K_{t}}$. The joint probability distribution that only fast or slower nodes will be transmitting at any time $t_{i}$ will be given as

$$
\operatorname{Pr}\left\{\tau_{s} \vee \tau_{f}\right\}=\rho^{K_{t}}+(1-\rho)^{K_{t}}
$$

This implies that both slower and faster nodes are transmitting in same or different cells will have the probability as given in equation 16

$$
\operatorname{Pr}\left\{\tau_{s} \wedge \tau_{f}\right\}=1-\left(\rho^{K_{t}}+(1-\rho)^{K_{t}}\right)
$$

Since contention base CSMA/CA protocol ensures equal long term probability of channel access to all nodes irrespective of their transmission rate, equation 14 implies that, the overall efficiency of a network is dependent on number of slower and faster nodes in that network. In this way, we have three possible scenarios.

1) Number of slower nodes is larger than number of faster nodes that result in $\tau_{s}>\left(1-\tau_{s}\right)$.

2) Number of slower nodes is equal to the number of faster nodes that results in $\tau_{s}=\left(1-\tau_{s}\right)$.

3) Number of slower nodes is less than number of faster nodes that results in $\tau_{s}<\left(1-\tau_{s}\right)$.

$$
T\left(n_{s}\right)=\left(B-B_{l}\right) \log _{2}\left(1+10 \log _{10} \frac{P d\left(U_{i}, K_{i}\right)^{-\alpha}}{\delta+P \beta\left(L_{i}\right) \sum \varphi\left(L_{i}, L_{j}\right) d\left(K_{i}, K_{j}\right)^{-\alpha}}\right)
$$

where $T\left(n_{s}\right)$ is the throughput of any slower node and $B_{l}$ is the surplus bandwidth that is not required by slower node. Similarly the throughput of faster node will be, 


$$
T\left(n_{f}\right)=\left(B+B_{l}\right) \log _{2}\left(1+10 \log _{10} \frac{P d\left(J_{i}, K_{i}\right)^{-\alpha}}{\delta+P \beta\left(L_{i}\right) \sum \varphi\left(L_{i}, L_{j}\right) d\left(K_{i}, K_{j}\right)^{-\alpha}}\right)
$$

\section{The proposed channel width adaptation algorithm}

In 802.11 networks the transmission rate of any node is a function of received signal strength (RSS) values. MIAP calculates the RSS and subsequent transmission rate of any node through channel reciprocity [14]. Based on these calculations, MIAP estimates the bandwidth requirement of a specific node and assigns channel of that width. At the initialization phase all the APs use standard non-overlapping channels. All APs are connected to a back-end management server through a wired link which controls all the activities like spectrum allocation, transmission rate determination etc. MIAP runs at this sever. The server calculates the optimal channel width and number of sub-carriers for the spectrum allocation to AP dynamically on the basis of transmission rate and RSS values.

If transmission rate changes at an AP, it is communicated to the management server. The AP releases or demands spectrum resource according to its current bandwidth status. If an AP needs more bandwidth, it notifies the server and the server check the status of available sub-carriers still not assigned to any AP. MIAP asks the server to check the demand considering the threshold values of RSS and transmission rate and decides if the increment in channel width is possible. Server then communicates the values of sub-carriers to the corresponding AP. After increasing the channel width AP starts spreading it signal by adding more frequencies to already in use sub-carriers.

On the other hand, if an AP has less bandwidth requirement it releases spectrum resource, which is added by the management server in its available pool of sub-carrier frequencies for its on demand dissemination to other APs on the network. If throughput requirement of an AP decreases at any given time it sends its new status to the management server. The management server checks the inuse sub-carriers and ask the AP to reduce its channel width by spreading its signal on lesser number of sub-carrier frequencies. Algorithm 1 explains the working of MIAP.

Result: Required Channel Bandwidth ( $C B$ )

Output: Channel Bandwidth (CB), Transmission Parameters (TP) begin

for $N_{i} \in N_{t}$ do

if $R S S\left(N_{i}\right) \leq R S S_{(\operatorname{Max})}$

then Calculate $T R_{\text {(current) }} \& \& T P \leftarrow T P$ for $C B_{\text {(current) }}$

else

f $T R<T R_{(\operatorname{Max})} \& \& R S S \geq R S S_{(\operatorname{Max})}$

then

$C B_{\text {(new) }} \leftarrow C B_{\text {current }}+1.875 \mathrm{MHz}$

while $T R\left(N_{i}\right)=T R\left(N_{i}\right)$ do

end

else

Return $C B($ new $) \& \& T P \leftarrow T P$ for $C B$ (nem)

end

if end

f $T R \geq T R_{(\operatorname{Max})}$

$C B_{\text {(new) }} \leftarrow C B_{\text {current }}-1.875 \mathrm{MHz}$;

while $T R\left(N_{i}\right)=T R\left(N_{i}\right)$ do

else

end

GoTO 16
24 end

Algorithm 1: MAC laver Independent Anomaly Prevention Algorithm

\section{Experimental setup and implementation}

For empirical evaluation of MIAP, we have deployed an indoor network of three USRP kits connected to laptops running GNU radio software on Linux operating system (OS). Fig. 1 shows the layout of deployed network. As proof of concept, implementation of MIAP for $802.11 \mathrm{~g}$ wireless networks has been made by significantly modifying transceiver implementation provided a CGRAN (Comprehensive GNU Radio Archive Network) website [3][10] and better explained in [6]. This implementation is extendable to any $\$ 802.11 \$$ standard, by modifying its parameters a physical layer accordingly.

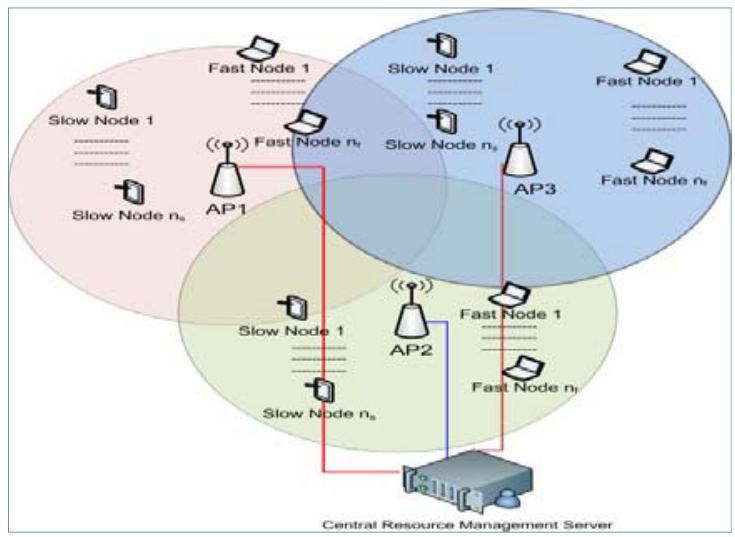

Fig 1: Topology of Experimental Network

A central management server constituted of Dell T-620 computer running MIAP on Linux OS has been placed for implementation of flexible channelization. Each USRP2 kit contained a 2400 RX/TX daughter card with omni-directional antennas. The specifications of USRP kit and daughter cards are available at website [7]. We have customized the physical layer of each AP in such a way that an AP can switch to any of narrower or wider channel widths at the end of current frame transmission. The wireless nodes detect the width of channels based on the preamble being transmitted by APs before the transmission of each frame.

\section{Performance results and discussion}

We performed a series of experiments to evaluate the effect of deploying MIAP on essential network performance parameters by using varying number of network nodes. We have deployed a network of $5,10,15,20,25$, and 30 nodes in each cell with varying number of slow and fast nodes. The obtained results are averaged out by collecting traces of all APs for accurate efficiency measuremen of MIAP.

We have evaluated our proposed algorithm for throughput gains for various ratio of slower and faster nodes. The slower nodes randomly choose their data rate from 6, 9, 12, 18. 24 and 36 (Mbps), while the faster nodes operate on maximum data rate they can achieve. The physical layer of faster nodes is modified to achieve maximum transmission rate. In some cases it is noted that TR of faster nodes may reach to $128 \mathrm{Mbps}$. The achieved results are compared with standard $802.11 \mathrm{~g}$ implementation, COTAM [12] and signal to noise ratio based contention window (SNR based CW) [2] 
Хуссейн А., Сафьн М., Сарвар С., Ул Кайум 3., Икбол М., Сакиб̆ Н.А. Сглаживание аномалий производительности сетей Wi-Fі на уровне МАС путем , том 31, вы. 2, 2019 г., стр. 53-66

The comparison given in fig. 2 demonstrate that presented algorithm outperforms all its counterparts and shows a significant improvement in achieved throughput when compared with standard implementation of $802.11 \mathrm{~g}$ physical layer. This improvement in achieved throughput becomes almost equal to $30 \%$ at some points. The reason behind this high throughput is the fact that, at any given time if a slower node in one cell is transmitting, the TR of faster node in other cell automatically increases. This increase in TR of faster cell diminishes the effect of slower node thus keeping the network wide average throughput on higher side.

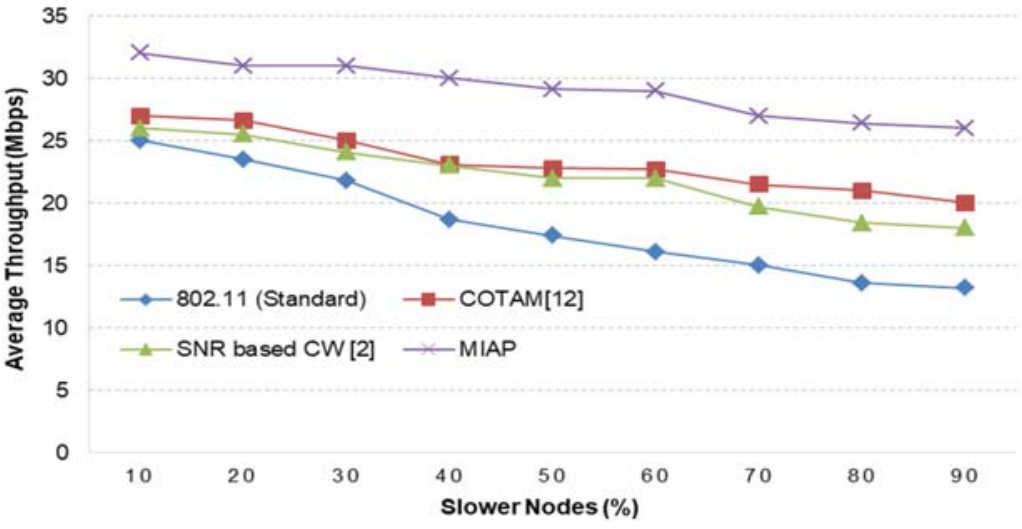

Fig 2: Average Network Wide Throughput Comparison

In fig 3, we evaluated the throughput performance of MIAP for slower and faster nodes and compared the results with standard 802.11 implementation. It is observed that MIAP significantly performs better than standard implementation due to better utilization of network resources. Since MIAP diverts surplus resources of slower cell to a faster cell which increases the efficiency of that cell without affecting the performance of slower cell. This efficient utilization of spectrum resources increases the average throughput of faster nodes. It is observed that for longer time intervals with nodes operating in saturation mode, the efficiency gains are significantly high.

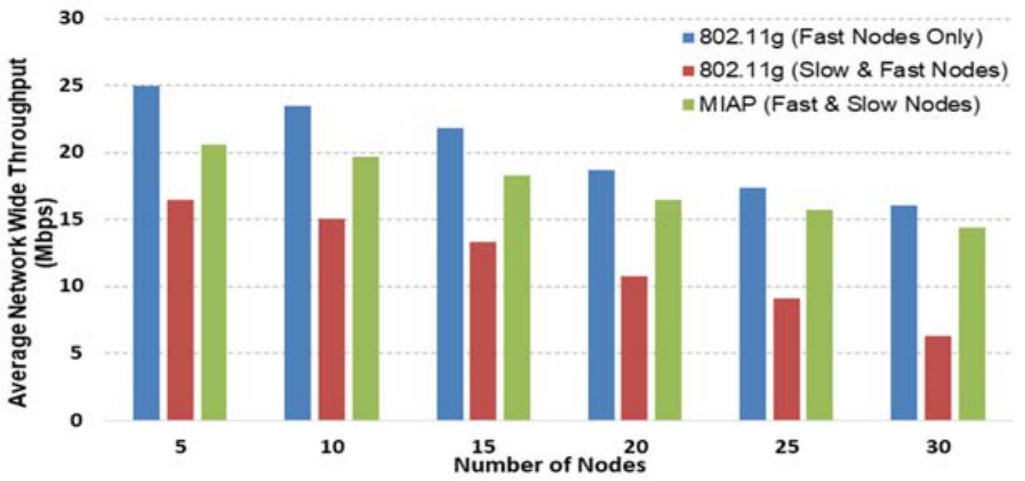

Fig 3: Average Network Wide Throughput Comparison

The results given in fig. 4 demonstrate the gain in average throughput of one cell with corresponding decrease of TR in adjacent cell. It is evident that if transmission rate of nodes in one cell decreases it automatically increases the TR of adjacent cell. It is noted that faster cell do not gain the exact throughput loss of slower cell. The reason behind this below par throughput gain is inefficiency of
Hussain A., Safyan M., Ul Qayyum Z., Sarwar S., Iqbal M., Saqib N.A. Mitigating MAC Layer Performance Anomaly of Wi-Fi Networks channel width detection mechanism. The rapid oscillation of channel width is not detected efficiently and some frames may loss in this process. This frame loss decreases the average throughput.

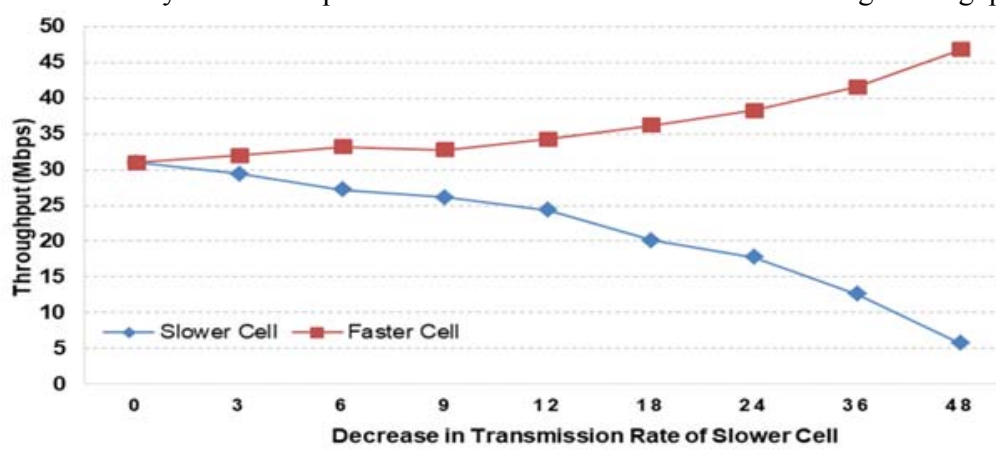

Fig 4: Average Network Wide Throughput Comparison

Fig 5 shows throughput of cell with faster node when TR of cell with slower nodes is fixed. The throughput comparison of MIAP for different MAC protocol data unit (MPDU) is given in Fig 6. The results show that longer the MAC fram higher will be the throughput. These results are selfexplanatory considering that longer frames reduce the per unit time overhead of communication thus maximizing the throughput. The adaptable nature of MIAP further increases the throughput by maximum utilization of frequency spectrum.
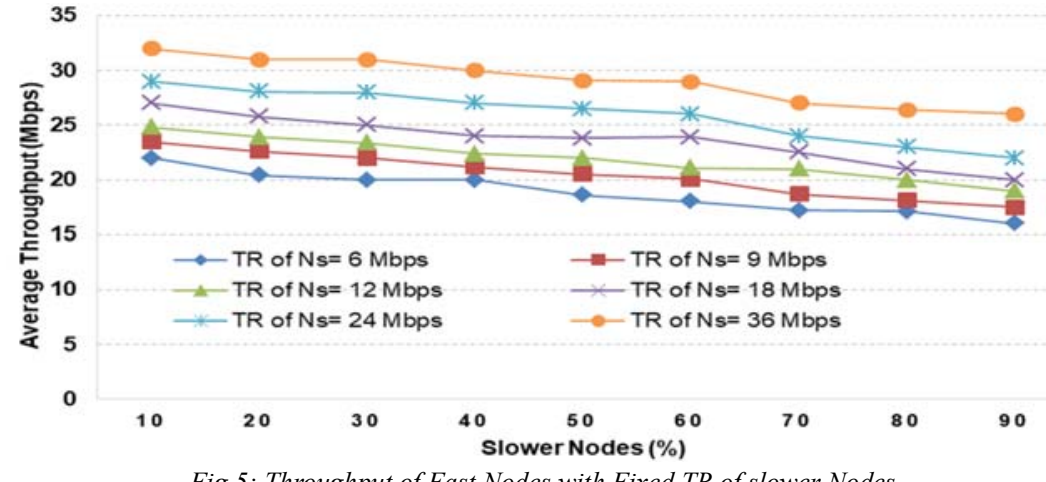

Fig 5: Throughput of Fast Nodes with Fixed TR of slower Nodes
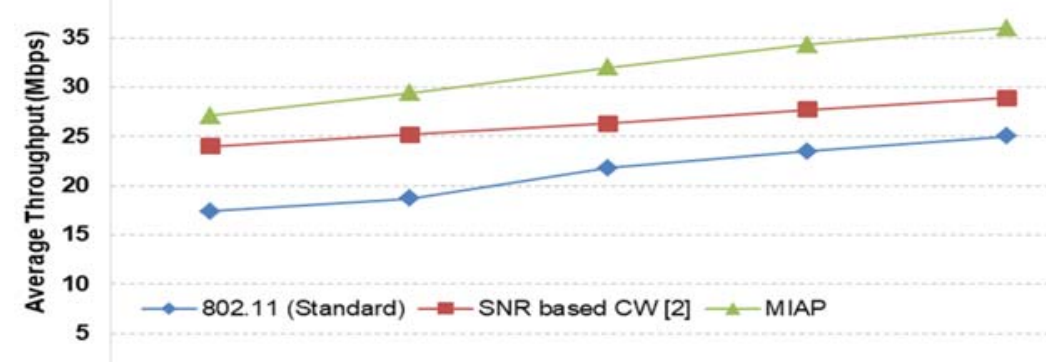

500

1000

1500

2000

2500 


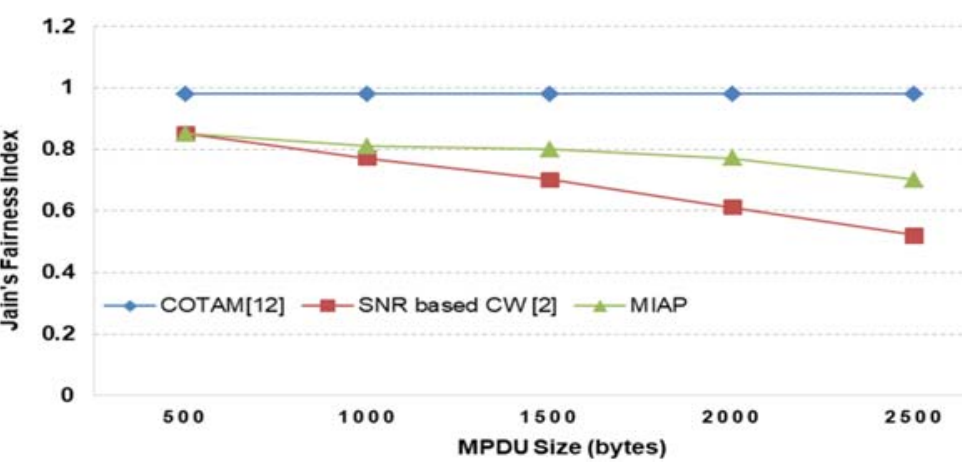

Fig 7: Channel Access Fairness for Various MPDU sizes

Finally, Fig 7 and Fig 8 show channel access fairness of MIAP for various sizes of MPDU and different number of nodes respectively. The achieved results depict that fairness of MIAP algorithm in granting channel access to various nodes is near to standard implementation. It is better than SNR based CW adaptation and below the performance of COTAM. Since MIAP is MAC layer independent mechanism and it does not change the channel access mechanism, therefore the fairness remains similar to standard implementation of $801.11 \mathrm{MAC}$. On the other hand SNR based CW adaptation performs poorly due to different sizes of contention window at different nodes.
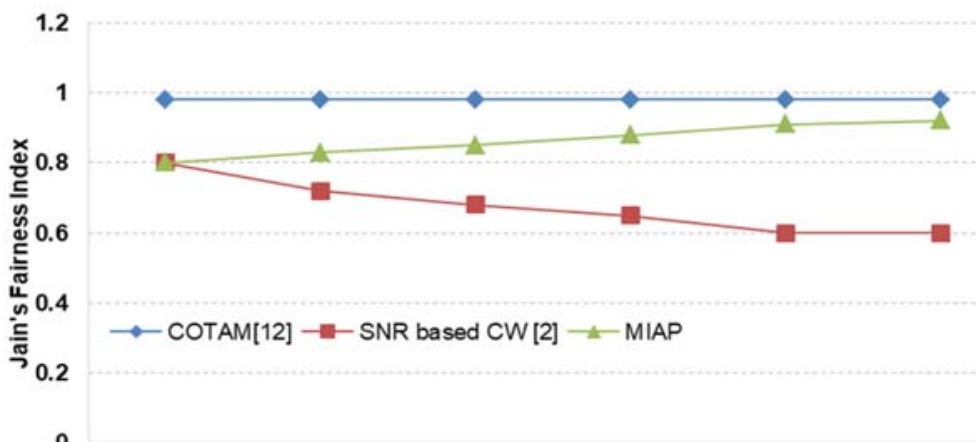

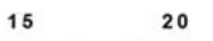

\section{Number of Nodes}

Fig 8: Channel Access Fairness for Different Number of Nodes

\section{Conclusion}

In this work, we propose an efficient mechanism to mitigate the effect of MAC layer performance anomaly by using adaptable width channelization in WLANs. The proposed algorithm assigns the channel widths based on transmission rate of nodes and divert the surplus frequency spectrum to resource hungry cells operating at higher transmission rates. We first probabilistically modeled the lower and upper bounds on number of slower and faster nodes in the network. In addition to this, we also analytically modeled the throughput and SINR of adaptable width channels. The evaluation of proposed algorithms is made based on throughput gains for different network settlements with varying number of slow and fast nodes. The throughput measurements show a significant improvement of more than $20 \%$ in achieved network capacity, with different combinations of slow and fast nodes. Moreover a detailed analysis on channel access fairness has also been presented. change at MAC layer, thus long term channel access probability remains same for each network node.

Future work includes the implementation of adaptable channel widths in MIMO based wireless networks like $802.11 \mathrm{n}$. In addition, development of a distributed channel adaptation algorithm that can assign spectrum resources locally on each AP is required. The effect of adaptable channelization on other essential network parameters like power consumption, transmission range, etc. is also needed to be explored.

\section{References}

[1]. 802.11-2012 - IEEE Standard for Information technology--Telecommunications and information exchange between systems Local and metropolitan area networks--Specific requirements Part 11: Wireles LAN Medium Access Control (MAC) and Physical Layer (PHY) Specifications. IEEE Std 802.11-2007 (Revision of IEEE Std 802.11-1999), 2007.

[2]. O.C. Branquinho, N. Reggiani, and D.M. Ferreira. Mitigating 802.11 mac anomaly using snr to contro back-off contention window. In Proc. of the International Conference Wireless and Mobile Communications, 2006 ,

[3]. The Comprehensive GNU Radio Archive Network (CGRAN). IEEE $802.11 \mathrm{a} / \mathrm{g} / \mathrm{p}$ ofdm transceiver. Available at: http://cgran.hopto.org/3000/, accessed 30.01.2019

[4]. Deepti Chafekar, V. S. Anil Kumar, Madhav V. Marathe, Srinivasan Parthasarathy, and Aravind Srinivasan. Capacity of wireless networks under sinr interference constraints. Wireless Network, vol. 17 Srinivasan. Capacity of wires
no. 7, 2011 pp. $1605-1635$.

[5]. Ranveer Chandra, Ratul Mahajan, Thomas Moscibroda, Ramya Raghavendra, and Paramvir Bahl. A case for adapting channel width in wireless networks. In Proc. of the ACM SIGCOMM 2008 Conference on Data Communication, 2008, pp. 135-146.

[6]. Andrea COSTANTINI. Implementation of an IEEE $802.11 \mathrm{p}$ transmitter in open-source Software Defined Radio. Master's thesis, Universit a del Salento, Piazza Tancredi, 2009.

[7]. Ettus Research, Universal Software Radio Peripheral and Daughter Boards, Available at: http://www.ettus.com/product/details/UN210-KIT, accessed 30.01.2019.

[8]. M. Heusse, F. Rousseau, G. Berger-Sabbatel, and A. Duda. Performance anomaly of 802.11b. In Proc. of the Twenty-Second Annual Joint Conference of the IEEE Computer and Communications, vol. 2, 2003, pp. 836-843.

[9]. Abid Hussain and Nazar A. Saqib. Effects of implementing adaptable channelization in wifi networks. Mobile Information Systems, 2016, $15 \mathrm{p}$

[10]. Abid Hussain, Nazar A. Saqib, Usman Qamar, Muhammad Zia, and Hassan Mahmood. Protocol-aware radio frequency jamming in wifi and commercial wireless networks. Journal of Communications and Networks, vol. 16, no. 4, 2014, pp. 397-406.

[11]. Seong il Hahm and Chong-Kwon Kim. Time-correlated fading can mitigate rate anomaly in ieee 802.11 wlans. In Proc. of the 9th International Symposium on Communications and Information Technology, 2009, pp. 560-561.

[12]. K. Kashibuchi, Y. Nemoto, and N. Kato. Mitigating performance anomaly of tfrc in multi-rate ieee 802.11 wireless lans. In Proc. of the Global Telecommunications Conference, 2009, pp. 1-6.

[13]. Won-Suk Kim, Sang-Hwa Chung, Chang-Woo Ahn, and Mi-Rim Do. Seamless handof and performance anomaly reduction schemes based on openow access points. In Proc. of the 28th International Conference on Advanced Information Networking and Applications Workshops, 2014, pages 316-321.

[14]. E. Larsson, O. Edfors, F. Tufvesson, and T. Marzetta. Massive mimo for next generation wireless system IEEE Communications Magazine, vol. 52, no. 2, 2014, pp. 186-195.

[15]. Yumei Liu, Bo Lv, and Yan Li. A new mac mechanism to resolve $802.11 \mathrm{~b}$ performance anomaly. In Proc. of the 2nd International Conference on Signal Processing Systems, vol. 3, 2010, pp. 134-138.

[16]. Shravan Rayanchu, Vivek Shrivastava, Suman Banerjee, and Ranveer Chandra. Fluid: Improving throughputs in enterprise wireless lans through exible channelization. IEEE Transactions on Mobile Computing, vol. 11, no. 9, 2012, pp. 1455-1469.

[17]. Herbert Taub and Donald L. Schilling. Principles of Communication Systems. McGraw-Hill Higher Education, 2nd edition, 1986. 


\section{Информация об авторах / Information about authors}

Абид ХУССЕЙН получил степень доктора философии в Национальном университете наук и технологий, Исламабад, Пакистан. Его исследовательские интересы включают адаптацию полос беспроводного канала, физические атаки и атаки уровня МАС в беспроводных сетях и стохастическое моделирование поведения беспроводных сетей на физическом уровне и уровне MAC.

Abid HUSSAIN received a Ph.D. degree at National University of Sciences and Technology, Islamabad, Pakistan. His research interests include wireless channel band adaptation, physical and MAC layer attacks in wireless networks and stochastic modelling of physical and MAC layer behaviour of wireless networks.

Мухаммад САФЬЯН работает в Правительственном университете колледжа, Лахор,

Пакистан. Он получил степень магистра в 2009 г. Национальном университете науки и

технологии. Область его научных интересов включает отображение онтологий, электронное обучение, семантическое распознавание активностей.

Muhammad SAFYAN is in Government College University (GCU), Lahore. He received his MS degree from National University of Sciences and Technology in 2009. His area of interest is ontology alignment, e-learning and semantic activity recognition.

Сохаил САРВАР получил степень магистра в области информационных технологий в Национальном университете науки и технологии, Исламабад, Пакистан. В настоящее время он готовит диссертацию на соискание степени $\mathrm{PhD}$ на Компьютерном факультете университета Гуджарата, Пакистан. Исследовательские интересы включают электронное обучение, семантические технологии и методы инженерии знаний.

Sohail SARWAR received the M.S. degrees in information technology from National University of Science and Technology. Islamabad, Pakistan. He is currently pursuing the Ph.D. degree in the Department of Computing, University of Gujrat Pakistan. His research interests include e-learning, semantic technologies and knowledge engineering techniques.

Зия УЛЬ КАЙУМ в настоящее время является профессором в университете Гуджарата в Пакистане. Он получил степень $\mathrm{PhD}$ в области компьютерных наук в Университете Лидса, Великобритания, в 2005 году. В число научных интересов входят искусственный интеллект, инженерия знаний, интеллектуальный анализ знаний, семантический Web и электронное обучение.

Zia UL QAYYUM is currently a professor at University of Gujrat, Pakistan. He received his Ph.D. degree in computer science from Leeds University UK in 2005. His research interests include artificial intelligence, knowledge engineering, data mining, semantic web and e-learning.

Муддессар ИКБАЛ работает старшим преподавателем в Лондонском университете Саут Бэнк и в университете Эссекса, Великобритания. Он получил степень $\mathrm{PhD}$ в Кингстонском университете, Лондон, Великобритания. Его научные интересы включают сетевые технологии $5 \mathrm{G}$, мультимедийные облачные вычисления, мобильные граничные вычисления, туманные вычисления, интернет вещей, программно-конфигурируемые сети, виртуализацию сетевых функций, качество восприятия, облачные инфраструктуры и службы.

Muddessar IQBAL is working as senior lecturer in London South Bank University and University of Essex, England. Dr. Iqbal completed his PhD from Kingston University in 2010. His research interests include $5 \mathrm{G}$ networking technologies, multimedia cloud computing, mobile edge computing, fog computing, Internet of Things, software-defined networking, network function virtualisation, quality of experience, and cloud infrastructures and services.

Назар Аббас САКИБ получил степень магистра наук в Университете Куэйд-и-Азам, Исламабад в 1993 году. Степень $\mathrm{PhD}$ в области электротехники получил в Центре исследований и перспективных исследований Национального политехнического института,
Мексика. Его исследовательские интересы включают компьютерную и коммуникационную безопасность, криптографическое оборудование и проектирование систем на основе FPGA. Nazar Abbas SAQIB recieved his master degree from Quaid-i-Azam University, Islamabad in 1993. He received his Ph.D. degree in Electrical Engineering from the Center for Research and Advanced Studies of the National Polytechnic Institute, Mexico. His research interests include computer and communication security, cryptographic hardware and FPGA based system design. 